\title{
$\mathrm{M}-\mathrm{IPA}$ 를 이용한 해수욕장 Barrier Free 환경조성 요소의 개선 우선순위 분석
}

최서연 ${ }^{1}$, 이석환 ${ }^{1 *}$, 신강원 $^{1}$

${ }^{1}$ 경성대학교 도시공학과

\section{Determining Improvement Priorities of Barrier Free Components for Beaches through M-IPA}

\author{
Seo-Yeon Choi ${ }^{1}$, Seok-Hwan Lee ${ }^{1^{*}}$ and Kang-Won Shin ${ }^{1}$ \\ ${ }^{1}$ Department of Urban Design \& Development, Kyungsung University
}

\begin{abstract}
요 약 많은 지자체들이 도시시설을 장애물 없는 (barrier free, BF) 환경으로 조성하기 위한 노력들을 기울이고 있 다. 그러나 선행연구는 장애인만을 주 분석대상으로 $\mathrm{BF}$ 환경 조성요소들을 도출한바 장애인과 비장애인의 공통개선 요소와 이용자별 개선요소를 고려한 $\mathrm{BF}$ 환경조성방안에 대한 연구는 미흡한 실정이다. 본 연구는 부산광역시 해수욕 장을 이용한 장애인과 비장애인의 $\mathrm{BF}$ 환경 조성요소들에 대한 만족도를 변형된 중요도-만족도 분석 (modified importance-performance analysis)기법을 적용하여 개선 우선순위를 도출하였다. 분석결과 장애인과 비장애인의 공통개 선요소인 “위생시설”의 개선이 가장 시급할 것으로 판단되며, 장애인을 대상으로는 “매개시설”의 개선이, 비장애인을 대상으로는 "편의시설"의 개선이 필요한 것으로 나타났다. 이러한 분석결과는 장애인과 비장애인이 대상 해수욕장 시설 이용 시 장애가 되는 요소들이 이용자의 특성에 따라 달라질 수 있음을 나타낸다. 본 연구는 장애인과 비장애 인의 $\mathrm{BF}$ 생활환경 조성 요소에 대한 만족도를 분석하여 공통개선요소와 각 이용자별 개선요소를 제시함으로서 $\mathrm{BF}$ 관련 정책수립과 예산책정에 유연성을 부여할 수 있을 것으로 기대된다.
\end{abstract}

\begin{abstract}
A number of cities are committed to enhancing the barrier-free (BF) environments. However, no attempts have been made to examine the $\mathrm{BF}$ environment design concept by accounting for the universal $\mathrm{BF}$ components, which should be improved for providing both disabled people and non-disabled people with better $\mathrm{BF}$ environments. With this challenge in mind, this study determines the improvement priorities of $\mathrm{BF}$ components for beaches in the city of Busan by investigating the results of satisfaction survey, which was administered to disabled and non-disabled visitors. The modified importance-performance analysis (M-IPA) results show that "sanitation facilities" are the universal BF components having the highest improvement priority. The analysis results also indicate that "access facilities" have the second highest improvement priority for disabled people while "amenity facilities" have the second highest improvement priority for non-disabled people. It is highly expected that the suggested improvement priorities of BF components can be used for policy makers to develop more flexible plans when designing the BF beach.
\end{abstract}

Key Words : Barrier free, Beach, Modified importance-performance analysis, Improvement priority

\section{1. 서론}

우리나라는 교통약자들의 다양한 도시 시설의 이용편 의를 증진하고 도로의 통행 장애요소를 제거하기 위해 "장애인·노인·임산부 등의 편의 증진 보장에 관한 법률"
과 “교통약자의 이동편의 증진법”을 시행하고 있다. 이와 더불어 “장애물 없는 생활환경 인증제도” (Barrier Free인 증제도, 이하 BF인증제도)를 2007년부터 추진하고 있다. 이는 도시, 교통수단, 건축물 등을 장애물 없는 생활환경 으로 조성하기 위한 제도적 장치로 장애인을 포함한 교

*교신저자 : 이석환 (1shsun@ks.ac.kr)

접수일 10 년 10 월 18 일 수정일 10 년 11 월 22 일

게재확정일 10 년 12 월 17 일 
통약자의 도시시설 이용 시 불편해소와 이동의 연속성을 확보하기 위한 노력의 일환이라 할 수 있다. 현재까지 진 행된 $\mathrm{BF}$ 인증 취득현황을 살펴보면 주로 서울, 경기도, 대 전의 건축물과 도로를 중심으로 이루어졌으며, 최근 부산 광역시도 관내 도심레저형 해수욕장을 장애물 없는 생활 환경으로 조성하기 위한 노력을 기울이고 있다. 그러나 해수욕장과 같은 도시 공원시설에 대한 $\mathrm{BF}$ 인증사례는 서울특별시의 광화문광장이 유일하고 특히 도심 내에 위 치한 해수욕장의 $\mathrm{BF}$ 생활환경 조성방향은 기존의 도심공 원과 다른 특성을 가질 수 있을 것으로 판단된다. 또한 기존의 연구는 장애인만을 중심으로 각종 시설을 $\mathrm{BF}$ 생 활환경으로 조성하기 위한 노력을 기울여 $\mathrm{BF}$ 관련 사업 은 장애인만을 위한 환경개선사업으로 치부된 경향이 있 다. 따라서 $\mathrm{BF}$ 관련 사업은 예산책정 및 정책도입 시 상 대적인 우선순위가 낮은 것이 현실인바 장애인뿐 아니라 비장애인의 의견을 반영하여 $\mathrm{BF}$ 생활환경 조성의 방향을 설정해야 할 것으로 판단된다. 이러한 연구 배경 하에 본 연구는 부산광역시의 광안리, 송도, 해운대 해수욕장을 $\mathrm{BF}$ 생활환경으로 조성하기 필요한 총 44개 항목에 대한 장애인과 비장애인의 만족도를 변형된 중요도-만족도 분 석 (modified importance- performance analysis, 이하 $\mathrm{M}-\mathrm{IPA}$ )기법을 적용하여 분석한 후, 부산광역시의 도심. 레저형 해수욕장을 $\mathrm{BF}$ 생활환경으로 조성하기 위해 요구 되는 이용자별 개선항목과 개선우선순위를 도출하였다.

\section{2. 이론적 고찰}

\section{1 연구동향}

다양한 도시시설을 $\mathrm{BF}$ 생활환경으로 조성하기 위해 많은 선행연구들이 추진되어 왔다. BF라는 용어는 1974 년 '장벽 없는 건축 설계(barrier free design)'라는 개념에 서 사용되기 시작했으며, 이후 일본·스웨덴·미국 등 선진 국을 중심으로 교통약자들도 일반인과 다름없는 도시생 활을 영위할 수 있도록 도시생활환경을 개선해야 한다는 운동이 전개되면서 그 필요성이 확산되었다.

2000 년 이후에는 $\mathrm{BF}$ 의 개념은 건축이나 도로·공공시 설의 건축요소들을 $\mathrm{BF}$ 화하는 물리적 $\mathrm{BF}$ 생활환경 조성 뿐 아니라 자격·시험 등에 장애인의 참여를 제한하는 제 도적 법률적 장벽을 비롯해 각종 차별과 편견, 나아가 장 애인 뿐 아니라 일시적 장애를 갖고 있는 교통약자들에 대한 심리적 장애물을 제거하는 것까지 확대되어 사용되 고 있다. 이러한 $\mathrm{BF}$ 개념을 평가할 수 있도록 우리나라는 2007년 BF 인증제도를 도입하여 각종 도시시설에 대한
교통약자의 접근, 이동, 이용편의의 원활성을 각 인증요 소에 대한 가중치를 적용하여 3 등급으로 평가하고 있다. 주요 인증대상은 도시구역 (10만이이상의 구역)과 개별 시설물로 구분되며, 개별시설물은 도로 및 교통수단, 공 원 및 건축물로 세분된다. [5]

표 1 은 $\mathrm{BF}$ 관련 선행연구들의 주요 결과를 연구대상, 연구내용, 연구방법에 따라 각각 분류하여 요약한 한 것 으로, 선행연구는 건축물, 공원, 도로을 연구대상으로 관 련 시설물을 $\mathrm{BF}$ 생활환경으로 조성하기 위한 개선방안을 제시한 연구, $\mathrm{BF}$ 생활환경의 기본 개념과 이를 구현하기 위한 지침 제시와 관련된 연구, 도시시설 이용자의 행동 관찰 및 만족도 조사를 통한 개선방안 제시와 관련된 연 구들로 나눌 수 있다. 이처럼 $\mathrm{BF}$ 생활환경 조성에 관한 연구는 다양한 측면에서 진행되어 왔으나, 기존 연구들은 장애인만을 주 연구대상으로 하고 있으며 공간적 범위도 공공시설물과 같은 개별건축물에 한정되어 있다.

[표 1] 주제별 선행연구 검토

\begin{tabular}{|c|c|c|c|}
\hline \multicolumn{2}{|c|}{ 구 분 } & 연구자 & 연구요약 \\
\hline \multirow[t]{2}{*}{$\begin{array}{l}\text { 대 } \\
\text { 상 } \\
\text { 별 }\end{array}$} & \begin{tabular}{|c|} 
개별 \\
시설물 \\
(건축물 \\
$\cdot \cdot$ \\
공원) \\
\end{tabular} & $\begin{array}{l}\text { 박창선 } \\
\text { [14] } \\
\text { 강병근 } \\
{[1,2,3]}\end{array}$ & $\begin{array}{c}\text { 공공업무시설, 유적기관, 지역 내 } \\
\text { 생활관련시설, 주택, 근린공원등 } \\
\text { 개별시설물과 공원의 장애인 } \\
\text { 편의시설을 대상으로 실태조사 및 } \\
\text { 문제점 도출 }\end{array}$ \\
\hline & 도로 & $\begin{array}{l}\text { 강준모 } \\
\text { [4] }\end{array}$ & $\begin{array}{c}\mathrm{BF} \text { 인증 모의평가를 통한 보행자 } \\
\text { 도로 } \\
\text { 개선 방안제시 }\end{array}$ \\
\hline \multirow{2}{*}{$\begin{array}{l}\text { 내 } \\
\text { 용 } \\
\text { 별 }\end{array}$} & 개념 & $\begin{array}{c}\text { 고치원 } \\
\text { [5] }\end{array}$ & $\begin{array}{c}\text { 장애물 없는 생활환경의 기본개념과 } \\
\text { 인증 절차에 관한 총론적 고찰 }\end{array}$ \\
\hline & 지침 & $\begin{array}{c}\text { 강병근 } \\
{[1]} \\
\end{array}$ & $\begin{array}{l}\text { 장애인 및 노약자들을 위한 설계의 } \\
\text { 기초적인 계획방향과 개선방안 제시 }\end{array}$ \\
\hline \multirow{2}{*}{$\begin{array}{l}\text { 방 } \\
\text { 법 } \\
\text { 별 }\end{array}$} & $\begin{array}{l}\text { 사례 } \\
\text { 연구 }\end{array}$ & $\begin{array}{l}\text { 조민정 } \\
\text { [6] } \\
\text { 강병근 } \\
{[1]} \\
\end{array}$ & $\begin{array}{c}\text { 국내외 선진시설방문으로 현장관찰 } \\
\text { 및 사용자 행동관찰을 통해 } \\
\text { 편의시설 실태 진단 및 개선방안 } \\
\text { 제시 }\end{array}$ \\
\hline & $\begin{array}{l}\text { 평가 } \\
\text { 연구 }\end{array}$ & $\begin{array}{l}\text { 김태호 } \\
\text { [11] }\end{array}$ & $\begin{array}{c}\text { M-IPA를 환용한 장애인과 } \\
\text { 비장애인의 만족도 비교를 통하여 } \\
\text { 장애인의 이동권 확보를 위한 } \\
\text { 서비스 개선사항 도출 }\end{array}$ \\
\hline
\end{tabular}

따라서 본 연구는 선행 연구와 달리 장애인과 비장애 인을 대상으로 부산광역시의 도심.레저형 해수욕장을 $\mathrm{BF}$ 생활환경으로 조성하기 위해 필요한 요소들을 도출하였 으며, 이를 위해 M-IPA 기법을 적용하였다.

\section{$2.2 \mathrm{M}-\mathrm{IPA}$ 기법}

중요도-만족도 분석 (Importance-Performance Analysis, 
IPA)기법은 마케팅 분야에서 주로 사용되는 기법으로, 한 서비스를 구성하는 다양한 요소들의 중요도와 만족도 를 조사하여 중요도를 수직축으로 만족도를 수평축으로 하는 실행격자 (action grid)를 구축하고 중요도와 만족도 의 중심경향치 (평균 혹은 중앙값)를 중심으로 실행격자 를 사분면으로 구분한 후 중심개선항목 (제 1 사분면), 노 력지속항목 (제 2 사분면), 개선요망항목 (제 3 사분면), 현상 유지항목 (제4사분면)을 도출한다[15]. 이러한 IPA 기법 을 본 연구에 적용했을 경우 부산시 해수욕장의 $\mathrm{BF}$ 인증 요소를 전술한 4 가지 항목으로 분류하여 제시할 수 있다 는 점에서 강점을 가지나, 전술한 바와 같이 본 연구의 목적은 장애인뿐 아니라 비장애인의 시설 만족도 분석을 통한 개선요소 도출인바 김태호 외 2인 (2009)의 연구에 서와 같이 장애인과 비장애인의 만족도를 상호 비교할 수 있는 변형된 중요도-만족도 분석 (M- IPA)기법을 적 용하였다 [11].

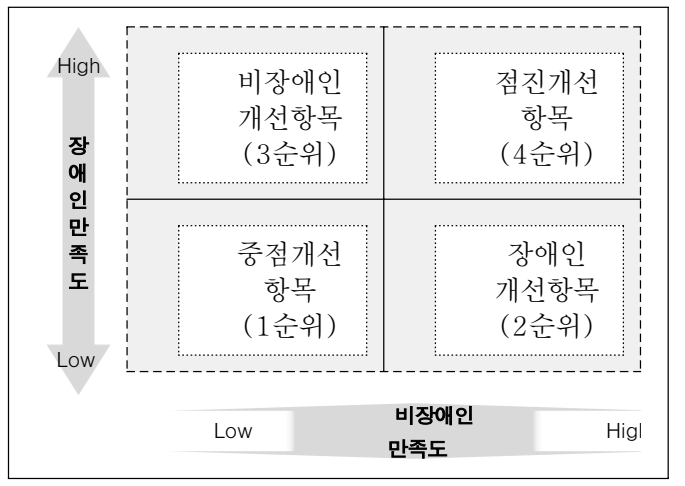

[그림 1] M-IPA분석 방법

M-IPA 기법은 그림 1 과 같이 비장애인의 만족도를 수 직축으로 장애인의 만족도를 수평축으로 하는 실행격자 를 구축한 후 이용자 별 만족도의 평균값을 중심으로 실 행격자를 사분면으로 구분한다. 변형된 실행격자에서 제 3 사분면은 비장애인의 만족도와 장애인의 만족도가 각 평균값보다 낮은 요소들로 구성된 중점개선항목을, 제 2 사분면은 장애인의 만족도가 장애인 만족도 평균보다 낮 은 요소들로 구성된 장애인 대상 개선항목을, 제 4 사분면 은 비장애인의 만족도가 비장애인 만족도 평균보다 낮은 요소들로 구성된 비장애인 대상 개선항목을, 제 1 사분면 은 장애인과 비장애인의 만족도가 각 평균값보다 높은 요소들로 구성된 점진개선항목을 포함한다.

\section{BF 만족도 조사}

\section{1 개요}

본 연구에서는 국토해양부 (2008)에서 제시한 공원시 설의 44개 인증항목 [13]을 부산광역시 도심 - 레저형 해 수욕장 (광안리·송도·해운대 해수욕장)을 $\mathrm{BF}$ 생활환경으 로 조성하기 위해 필요한 44개 항목으로 설정하였다. 각 항목에 대한 만족도는 2010년 8월15일부터 8월28일까지 13 일 동안 해당 해수욕장을 방문한 비장애인 270 명과 해 당 해수욕장을 방문한 경험이 있는 장애인 50 명을 대상 으로 면접 설문조사를 통해 수집하였으며, 44 개 설문요 소에 대한 설문의 일관성을 평가하기 위해 신뢰도 분석 을 수행하였다. 크론바하 알파에 대한 일반적인 기준으로 Nunally(1978)에 따르면 실험적인 연구의 경우 계수값이 0.7 이상이면 신뢰성이 있다고 한다. 표 2 와 같이 $\alpha$-계수 값이 장애인은 0.968 , 비장애인은 0.855 로 이 값이 0.7 보 다 높으므로 설문조사 자료는 신뢰성이 있다고 판단할 수 있다.

[표 2] 신뢰도 분석결과

\begin{tabular}{|c|c|c|}
\hline 구 분 & N of Item & Cronbach's Alpha \\
\hline 장애인 & 44 & 0.968 \\
\hline 비장애인 & 44 & 0.855 \\
\hline
\end{tabular}

\section{$3.2 \mathrm{BF}$ 인증 항목별 만족도}

표 3은 전술한 44 개 $\mathrm{BF}$ 생활환경 조성 항목에 대한 장 애인과 비장애인의 만족도 평균으로, 전반적으로 장애인 의 만족도 평균 (2.30)은 비장애인의 만족도 평균 (3.19) 보다 낮음을 알 수 있다. 이러한 조사결과는 장애인이 체 감하는 해수욕장 시설의 접근, 이용, 이동장애의 정도가 비장애인에 비해 큼을 나타내며, 비장애인의 만족도 평균 은 보통을 약간 상회하는 수준으로 나타나 비장애인 또 한 대상 해수욕장을 접근, 이용, 이동시 개선되어야 할 장 애요소가 있다고 인식하고 있음을 나타낸다.

[표 3] BF 환경조성 항목별 만족도 평균

\begin{tabular}{|c|c|c|c|c|c|}
\hline \multirow{2}{*}{\multicolumn{2}{|c|}{$\begin{array}{c}\mathrm{BF} \text { 생활환경 } \\
\text { 조성요소 }\end{array}$}} & \multirow{2}{*}{\multicolumn{2}{|c|}{ 세부항목 ${ }^{1)}$}} & \multicolumn{2}{|c|}{ 만족도평균 $^{2)}$} \\
\hline & & & & \multirow{2}{*}{$\frac{\text { 장애인 }}{2.73}$} & \multirow{2}{*}{$\begin{array}{c}\text { 비장애인 } \\
3.37 \\
\end{array}$} \\
\hline \multirow{7}{*}{$\begin{array}{l}\text { 매 } \\
\text { 개 } \\
\text { 시 } \\
\text { 설 } \\
\text { (a) }\end{array}$} & \multirow{7}{*}{ 접근로 } & 1 & 주출입구까지의 접근로 & & \\
\hline & & 2 & 유효폭 & 2.76 & 3.39 \\
\hline & & 3 & 단차 & 2.35 & 3.38 \\
\hline & & 4 & 기울기 & 2.29 & 3.45 \\
\hline & & 5 & 바닥 마감 & 2.64 & 3.49 \\
\hline & & 6 & 보행장애물 & 2.47 & 3.37 \\
\hline & & 7 & 덮개 & 2.75 & 3.26 \\
\hline
\end{tabular}




\begin{tabular}{|c|c|c|c|c|c|}
\hline \multirow{2}{*}{\multicolumn{2}{|c|}{$\begin{array}{l}\mathrm{BF} \text { 생활환경 } \\
\text { 조성요소 }\end{array}$}} & \multirow{2}{*}{\multicolumn{2}{|c|}{ 세부항목 ${ }^{1)}$}} & \multicolumn{2}{|c|}{ 만족도평균 ${ }^{2)}$} \\
\hline & & & & \multirow{2}{*}{$\begin{array}{c}\text { 장애인 } \\
2.09\end{array}$} & \multirow{2}{*}{$\frac{\text { 비장애인 }}{3.38}$} \\
\hline & \multirow{5}{*}{$\begin{array}{l}\text { 장애인 } \\
\text { 전용 } \\
\text { 주차 } \\
\text { 구역 }\end{array}$} & 8 & $\begin{array}{c}\text { 주차장 출입구까지 } \\
\text { 경로 }\end{array}$ & & \\
\hline & & 9 & 주차면수확보 & 1.69 & 2.94 \\
\hline & & 10 & 주차면 & 1.71 & 2.92 \\
\hline & & 11 & 보행안전통로 & 2.11 & 3.38 \\
\hline & & 12 & 안내 및 유도표시 & 1.78 & 3.19 \\
\hline & \multirow{2}{*}{$\begin{array}{l}\text { 주출 } \\
\text { 입구 }\end{array}$} & 13 & 진출입 통제계획 & 2.54 & 3.10 \\
\hline & & 14 & $\begin{array}{c}\text { 공원입구와 보도와의 } \\
\text { 경계 }\end{array}$ & 2.37 & 3.29 \\
\hline & \multicolumn{3}{|r|}{ 소계 ${ }^{3)}$} & 2.61 & 3.39 \\
\hline \multirow{5}{*}{$\begin{array}{c}\text { 유도 } \\
\text { 및 } \\
\text { 안내 } \\
\text { 시설 } \\
\text { (b) }\end{array}$} & \multirow{4}{*}{$\begin{array}{l}\text { 안내 } \\
\text { 설비 }\end{array}$} & 15 & 안내판 설치 & 2.24 & 3.19 \\
\hline & & 16 & 안내판의 정보 & 2.16 & 3.29 \\
\hline & & 17 & 통합안내 설비 & 1.91 & 2.46 \\
\hline & & 18 & 경고시설 & 2.26 & 3.16 \\
\hline & \multicolumn{3}{|r|}{ 소계 } & 3.00 & 3.42 \\
\hline \multirow{15}{*}{$\begin{array}{l}\text { 위 } \\
\text { 생 } \\
\text { 시 } \\
\text { 설 } \\
\text { (c) }\end{array}$} & \multirow{2}{*}{$\begin{array}{l}\text { 장애인 } \\
\text { 이용 } \\
\text { 가능한 } \\
\text { 화장실 }\end{array}$} & 19 & 장애유형별 대응 방법 & 2.30 & 3.03 \\
\hline & & 20 & 안내표지판 & 2.44 & 3.04 \\
\hline & \multirow{3}{*}{$\begin{array}{c}\text { 화장실 } \\
\text { 접근 }\end{array}$} & 21 & 유효폭 및 접근 & 2.13 & 3.37 \\
\hline & & 22 & 바닥 마감 & 2.19 & 3.11 \\
\hline & & 23 & 출입구(문) & 2.25 & 3.20 \\
\hline & \multirow{5}{*}{ 대변기 } & 24 & 칸막이 출입문 & 2.44 & 3.21 \\
\hline & & 25 & 활동 공간 & 2.64 & 3.09 \\
\hline & & 26 & 형태 & 2.38 & 3.15 \\
\hline & & 27 & 손잡이 & 2.56 & 3.21 \\
\hline & & 28 & 기타설비 & 2.51 & 2.64 \\
\hline & 소변기 & 29 & 형태 및 손잡이 & 2.70 & 3.07 \\
\hline & \multirow{3}{*}{ 세면대 } & 30 & 형태 & 2.45 & 3.16 \\
\hline & & 31 & 거울 & 2.49 & 3.27 \\
\hline & & 32 & 수도꼭지 & 2.63 & 2.90 \\
\hline & \multicolumn{3}{|r|}{ 소계 } & 2.54 & 3.23 \\
\hline \multirow{6}{*}{$\begin{array}{l}\text { 편 } \\
\text { 의 } \\
\text { 시 } \\
\text { 설 } \\
\text { (d) }\end{array}$} & \multirow{2}{*}{$\begin{array}{l}\text { 접근 및 } \\
\text { 이용성 }\end{array}$} & 33 & 시설까지의 접근로 & 2.57 & 3.30 \\
\hline & & 34 & 공원시설의 주출입구 & 2.19 & 3.25 \\
\hline & $\begin{array}{l}\text { 공원시 } \\
\text { 설 }\end{array}$ & 35 & 장애인을 배려한 공원 & 1.82 & 3.17 \\
\hline & \multirow{3}{*}{$\begin{array}{c}\text { 설 } \\
\text { 기타 } \\
\text { 설비 }\end{array}$} & 36 & 휴식공간 & 1.99 & 3.46 \\
\hline & & 37 & 매표소, 판매기, 음료대 & 2.00 & 3.25 \\
\hline & & & 소계 & 3.00 & 3.26 \\
\hline \multirow{8}{*}{$\begin{array}{l}\mathrm{BF} \\
\text { 보 } \\
\text { 행 } \\
\text { 의 } \\
\text { 연 } \\
\text { 속 } \\
\text { 성 } \\
\text { (e) }\end{array}$} & \multirow{7}{*}{$\begin{array}{c}\text { 공원 } \\
\text { 내부 } \\
\text { 보행로 }\end{array}$} & 38 & $\mathrm{BF}$ 보행로의 지정 & 2.43 & 3.44 \\
\hline & & 39 & 보행안전공간 & 2.74 & 3.35 \\
\hline & & 40 & 단차 & 2.19 & 3.25 \\
\hline & & 41 & 기울기 & 2.07 & 3.30 \\
\hline & & 42 & 바닥마감 & 2.81 & 3.33 \\
\hline & & 43 & 자전거도로와의 접점 & 2.70 & 2.92 \\
\hline & & 44 & 보행유도의 연속성 & 2.54 & 3.13 \\
\hline & \multicolumn{3}{|r|}{ 소계 } & 2.84 & 3.62 \\
\hline \multicolumn{4}{|r|}{ 총계 } & 2.30 & 3.19 \\
\hline
\end{tabular}

1) 세부항목별 설명은 국토해양부 (2008) “장애물 없 는 생활환경 인증기준” 참조 [15]

2) 만족도는 5점 척도 (1: 매우 불만족 5 : 매우 만 족)로 측정

3) 각 요소별 만족도 평균은 5 개 요소만(a-e)을 대상 으로 한 설문결과임

\section{M-IPA 적용결과}

\subsection{M-IPA 적용결과 : $\mathrm{BF}$ 생활환경 조성요소}

해수욕장을 $\mathrm{BF}$ 생활환경으로 조성하기 위한 5 개 요소 에 대한 M-IPA 분석결과를 살펴보면, 중점개선항목은 "위 생시설", 장애인 개선항목은 “매개시설", 비장애인 개선항 목은 “편의시설”, 점진개선항목은 “유도 및 안내시설”과 "BF 보행의 연속성"으로 나타났다 ([그림 2-A] 참조).

구체적으로 “위생시설”은 화장실의 평면구성, 화장실 접근용이성, 화장실 부속시설 (대변기, 소변기, 세면대)을 세부항목으로 포함하고 있으며, M-IPA 기법 적용결과 장 애인뿐 아니라 비장애인들의 해수욕장 위생시설 만족도 가 가장 낮은 것으로 나타나 모든 이용객들의 불편을 제 거하기 위한 $\mathrm{BF}$ 환경 조성을 목표로 할 경우 “위생시설" 의 장애요소를 중점적으로 개선해야 할 것으로 판단된다.

장애인 대상 중점개선사항은 외부에서 해수욕장으로 의 접근을 위해 사용되는 주차장, 주차장과 주출입구간 경로, 외부 보도에서 주출입구간 경로 상 시설로 구성된 "매개시설"인 것으로 나타났으며, 비장애인 대상 중점 개 선사항은 해수욕장 내 휴식공간, 매표소 및 판매기로 구 성된 “편의시설"인 것으로 분석되었다. 이러한 결과는 해 수욕장 이용객의 특성을 반영하는 것으로 장애인의 경우 대상 해수욕장으로 접근하기 위해 조성된 “매개시설"의 장애요소 개선이 “위생시설"의 장애요소 개선 다음으로 개선되어야 할 요소로 인식하고 있는 반면, 비장애인은 해수욕장 매개시설의 장애로 인한 불편함은 어느 정도 용인할 수 있으나 “편의시설"의 장애요소 개선이 "위생 시설"의 장애요소 개선 다음으로 추진되어야 할 것으로 인식하고 있음을 나타낸다.

한편 점진개선항목으로 분석된 "BF 보행의 연속성”에 대한 장애인 만족도가 “유도 및 안내시설”에 대한 장애 인 만족도에 비해 낮게 나타나 장애인들의 만족도를 고 려하여 개선 우선순위를 결정할 경우 "BF 보행의 연속 성”과 관련된 장애요소의 개선이 “유도 및 안내시설”과 관련된 장애요소의 개선보다 시급한 것으로 판단된다.

[표 4] 개선 우선순위

\begin{tabular}{|c|c|}
\hline 구 분 & 우선순위 \\
\hline 위생시설 & 1 \\
\hline 매개시설 & 2 \\
\hline 편의시설 & 3 \\
\hline BF보행의 연속성 & 4 \\
\hline 유도 및 안내시설 & 5 \\
\hline
\end{tabular}




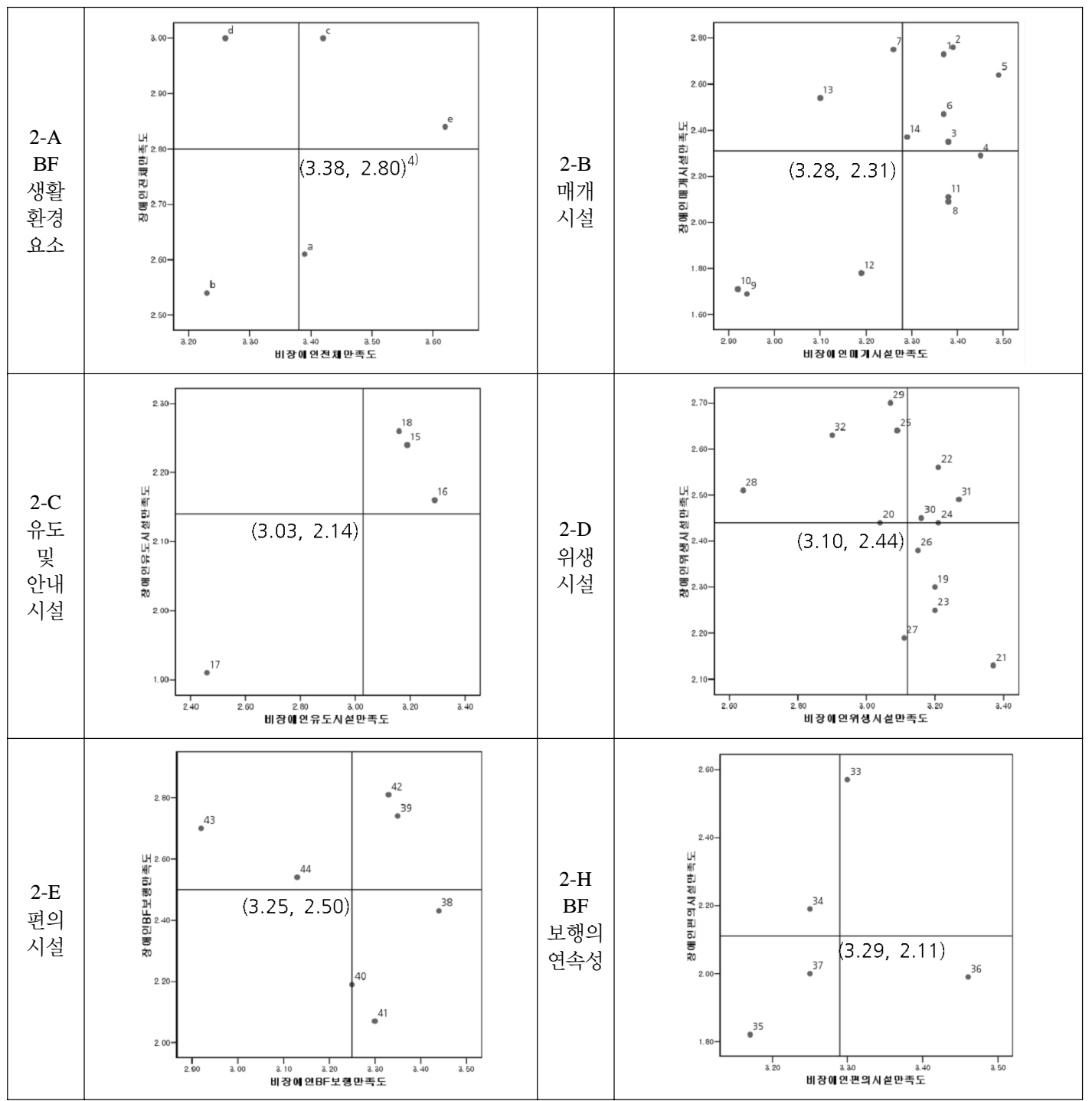

[그림 2] M-IPA 분석결과

4) (비장애인 만족도평균, 장애인 만족도평균)을 의미함

전술한 M-IPA 기법 결과를 반영하여 5 개 요소의 개선 우선순위를 도출하였으며, 본 연구에서는 장애인과 비장 애인의 만족도가 모두 낮게 나타나는 중점개선항목인 "위생시설"을 1순위, 장애인 대상 개선항목인 "매개시설" 을 2순위, 비장애인 개선항목인 “편의시설"을 3순위, 점 진개선항목인 "BF 보행의 연속성”과 “유도 및 안내시설” 을 각각 4순위와 5순위로 결정하였다 ([표 4] 참조). 물론 전술한 개선 우선순위는 예산책정 및 정책추진 의지에 따라 비장애인을 우선대상으로 할 경우 그 순서가 변화 할 수 있으나 본 연구에서는 장애인과 비장애인의 만족 도를 모두 고려한 결과를 최종 우선순위로 제시하였다.

\section{$4.2 \mathrm{M}-\mathrm{IPA}$ 적용결과 : 세부항목}

본 절에서는 전술한 $\mathrm{BF}$ 생활환경 조성 5 개 요소별 세 부항목에 대한 M-IPA 적용결과를 제시하였다. 각 요소 (매개시설, 위생시설, 유도 및 안내시설, 편의시설, $\mathrm{BF}$ 보 행의 연속성)별 실행격자를 사분면으로 분류하기 위해 각 요소별 세부항목 전체에 대한 장애인과 비장애인의 만족도 평균값을 사용하였으며, 각 요소별 중점개선사항, 장애인 대상 개선사항, 비장애인 대상 개선사항, 점진개 선항목은 그림 2에 나타냈다. 
[표 5] M-IPA 분석 결과

\begin{tabular}{|c|c|c|}
\hline 구분 & & 세부항목 \\
\hline \multirow{4}{*}{$\begin{array}{l}1 \\
\text { 순 } \\
\text { 위 }\end{array}$} & 매개시설 & 주차면수확보, 주차면, 안내 및 유도표시 \\
\hline & 위생시설 & 화장실 접근 시 바닥마감 \\
\hline & $\begin{array}{l}\text { 유도 및 } \\
\text { 안내시설 }\end{array}$ & 통합안내설비 \\
\hline & 편의시설 & $\begin{array}{l}\text { 교통약자를 배려한 놀이 공간, 매표소, } \\
\text { 판매기, 음료대 }\end{array}$ \\
\hline \multirow{4}{*}{$\begin{array}{l}2 \\
\text { 순 } \\
\text { 위 }\end{array}$} & 매개시설 & $\begin{array}{l}\text { 기울기, 주차장에서 출입구까지의 경로, } \\
\text { 보행안전통로 }\end{array}$ \\
\hline & 위생시설 & $\begin{array}{l}\text { 장애유형별 대응 방법, 화장실 접근 시유 } \\
\text { 효폭 및 단차, 출입문, 대변기 형태 }\end{array}$ \\
\hline & 편의시설 & 휴식 공간 \\
\hline & $\begin{array}{c}\mathrm{BF} \text { 보행의 } \\
\text { 연속성 }\end{array}$ & $\mathrm{BF}$ 보행로의 지정, 단차, 기울기 \\
\hline \multirow{4}{*}{$\begin{array}{l}3 \\
\text { 순 } \\
\text { 위 }\end{array}$} & 매개시설 & 덮개, 진출입통제계획 \\
\hline & 위생시설 & $\begin{array}{l}\text { 안내표지판, 대변기 활동 공간, 대변기 } \\
\text { 기타설비, 소변기의 형태 및 손잡이, } \\
\text { 수도꼭지 }\end{array}$ \\
\hline & 편의시설 & 공원시설주출입구 \\
\hline & $\begin{array}{l}\mathrm{BF} \text { 보행의 } \\
\text { 연속성 }\end{array}$ & 자전거 도로와의 접점, 보행유도의연속성 \\
\hline \multirow{5}{*}{$\begin{array}{l}4 \\
\text { 순 } \\
\text { 위 }\end{array}$} & 매개 시설 & $\begin{array}{l}\text { 주출입구까지의 접근로, 유효폭, 단차, 바 } \\
\text { 닥마감, 보행 장애물, 공원입구와 보도와 } \\
\text { 의 경계 }\end{array}$ \\
\hline & 위생 & $\begin{array}{l}\text { 대변기 손잡이, 대변기칸막이 출입문, } \\
\text { 세면대 형태, 세면대 거울 }\end{array}$ \\
\hline & $\begin{array}{l}\text { 유도 및 } \\
\text { 안내시설 }\end{array}$ & 안내판설치, 안내판의 정보, 경고시설 \\
\hline & 편의시설 & 시설까지의 접근로 \\
\hline & $\begin{array}{l}\mathrm{BF} \text { 보행의 } \\
\text { 연속성 }\end{array}$ & 보행안전공간, 바닥마감 \\
\hline
\end{tabular}

전장과 마찬가지로 장애인과 비장애인의 만족도를 모 두 고려한 M-IPA 결과를 이용하여 각 요소별 세부항목 에 대한 개선우선순위를 도출하였으며, 그 결과는 표 5 와 같다. 도출 결과를 살펴보면 개선 1순위인 각 요소 별 중 점개선 세부항목은 장애인뿐 아니라 비장애인들이 해수 욕장 이용 시 불편함을 느낄 수 있는 장애항목들로 구성 되어 있음을 알 수 있다 (예를 들어 주차면, 통합안내시 설, 화장실 바닥마감, 놀이공간 등). 개선 2순위는 각 요 소 별 장애인 대상 개선세부항목으로 장애유형별 위생시 설의 형태, $\mathrm{BF}$ 보행로 및 주출입구의 단차 등과 같은 항 목들로 구성되어 있으며, 개선 3순위로는 각 요소 별 비 장애인 대상 개선세부항목으로 비장애인들이 해수욕장 시설을 이용할 때 장애요소로 작용할 수 있는 안내표지 판, 진출입통제계획, 자전거 도로와의 접점 등이 선정되 었다. 마지막으로 개선 4순위는 각 요소 별 점진개선세부 항목으로 장애인과 비장애인이 해수욕장 시설을 이용함 에 있어 상대적으로 큰 불편을 느끼지 않는 장애항목들 인 안내판의 정보, 경고시설, 세면대 형태 등이 선정되었
다. 이러한 결과는 개선 4순위에 해당하는 세부항목에 대 한 개선이 불필요하다는 것을 의미하는 것은 아니며 타 세부항목에 비해 개선 사업 추진의 시급도가 상대적으로 낮다는 것을 나타낸다.

\section{5. 결론 및 향후과제}

본 연구는 장애인과 비장애인을 대상으로 부산광역 시 도심 레저형 해수욕장 (광안리, 송도, 해운대 해수욕 장)의 접근 이동 - 편의 시설에 대한 만족도를 M-IPA 기법을 이용하여 분석하였으며, 그 분석결과를 이용하여 도심 · 레저형 해수욕장을 $\mathrm{BF}$ 생활환경으로 조성하기 위 한 요소 및 세부항목들의 개선우선순위를 도출하였다. 구 체적인 분석결과는 다음과 같다.

분석 대상 해수욕장을 $\mathrm{BF}$ 생활환경으로 조성하기 위 해 필요한 요소들에 대한 장애인의 만족도는 비장애인의 만족도에 비해 전반적으로 낮게 나타났으며, 특히 장애인 의 만족도는 “보통 이하”로 분석되었다. 이러한 결과는 장애인들이 분석 대상 해수욕장 시설의 접근, 이용, 이동 시 체감하는 장애의 정도가 매우 커 분석 대상 해수욕장 을 $\mathrm{BF}$ 환경으로 조성하기 노력이 시급히 추진되어야 함 을 나타낸다.

한편 $\mathrm{BF}$ 생활환경 조성 세부항목에 대한 비장애인의 만족도는 “보통을 약간 상회”하는 것으로 나타났다. 이는 장애인 뿐 아니라 비장애인들도 대상 해수욕장을 접근, 이용, 이동시 개선되어야 할 장애요소가 있다고 인식하고 있음을 나타낸다. 특히 전술한 비장애인의 만족도 조사결 과는 장애인 뿐 아니라 비장애인의 장애요소를 모두 고 려하여 대상 해수욕장을 $\mathrm{BF}$ 생활환경으로 조성하여야 함 을 의미한다.

따라서 장애인과 비장애인의 $\mathrm{BF}$ 생활환경 조성 요소 에 대한 만족도를 M-IPA 기법을 이용하여 분석하였으며, 그 결과 중점개선항목은 “위생시설", 장애인 대상 개선항 목은 “매개시설", 비장애인 개선항목은 “편의시설", 점진 개선항목은 "BF 보행의 연속성”과 “유도 및 안내시설”로 분석되었다. 이러한 분석결과는 장애인과 비장애인이 대 상 해수욕장을 접근, 이용, 이동하는데 있어 장애가 되는 요소들이 이용자의 특성에 따라 달라질 수 있음을 나타 낸다.

각 요소별 개선 우선순위는 장애인과 비장애인의 만족 도 설문결과를 모두 고려했을 때 장애인과 비장애인의 공통개선요소인 "위생시설"의 개선이 가장 시급할 것으 로 판단되며, "매개시설", “편의시설", "BF 보행의 연속 성”, “유도 및 안내시설”의 순으로 각 요소별 장애요인이 
개선되어야 할 것으로 사료된다.

또한 각 요소별 세부항목에 대한 만족도를 M-IPA 기 법을 이용해 분석하였다. 분석 결과 개선 1 순위는 주차면 수확보, 주차면적, 안내 및 유도 표시, 화장실 접근 시 바 닥마감, 통합안내 설비, 장애인을 배려한 놀이 공간, 매표 소, 판매기, 음료대로 나타났으며, 개선 2순위는 주출입 구 기울기, 주차장에서 출입구까지의 경로, 보행안전통 로, 장애유형별 대응 방법, 화장실 접근 시 유효폭 및 단 차, 출입문, 대변기 형태, 휴식공간, $\mathrm{BF}$ 보행로의 지정 등 으로 나타났다.

각 요소별 세부항목에 대한 M-IPA 기법 적용결과 또 한 이용자의 특성에 따라 각기 다른 장애요소가 있음을 나타내고 있으며, 특히 전술한 개선 1,2 순위에 해당하 는 장애요소들은 분석 대상 도심·레저형 해수욕장을 $\mathrm{BF}$ 생활환경으로 조성하기 위해 시급히 개선되어야 할 것으 로 판단된다.

본 연구는 장애인만을 대상으로 추진되어 왔던 기존 $\mathrm{BF}$ 관련 연구들과 달리 장애인과 비장애인의 $\mathrm{BF}$ 생활환 경 조성 요소에 대한 만족도를 분석하여 공통개선요소와 각 이용자별 개선요소를 제시함으로서 $\mathrm{BF}$ 관련 정책수립 과 예산책정에 유연성을 부여했다는 측면에서 선행연구 와 큰 차별성을 갖는다. 그러나 본 연구는 부산광역시 도 심 레저형 해수욕장의 이용객만을 대상으로 결과를 도 출한바 본 연구결과를 일반화시키기 위해서는 지속적인 후속연구가 추진되어야 할 것으로 판단된다. 또한 설문표 본부족으로 해수욕장 이용자 중 다양한 교통약자(임산부, 어린이, 노약자, 15 종 장애)에 대한 세부 만족도분석을 수행하지 못한 아쉬움이 있다. 향후 이에 대한 보완연구 도 추진되어야 할 것으로 판단된다.

\section{참고문헌}

[1] 강병근 · 박광재 · 정현정 · 강지혜 · 이주형, "일본 베리어프리 공원의 사례분석을 통한 국내 도시공 원의 계획 방향에 관한 연구”, 대한건축학회지, 제 23권, 제12호, pp. 95-102, 12월, 2007.

[2] 강병근 - 성기창 - 박광재 김상운 김인순 이규 일 · 강태성 - 이기정 · 노지혜, "궁 · 능 · 유적기관 의 장애인편의시설 실태분석에 관한 연구”, 한국 의료복지시설학회지, 제 16 권 1호, pp. 7-16, 2월, 2010.

[3] 강병근 - 윤영삼 - 김은경, "장애인 및 노약자의 이 동편의 증진을 위한 교통광장의 실태평가", 대한 주거학회 논문지, 통권 254호, pp. 53-60, 2009.
[4] 강준모 - 이건록, "Barrier Free 인증 모의평가를 통 한 보행자도로 개선 방안에 관한 연구”, 대한토목 학회논문집, 제29권 제1호, pp.101-110, 2009.

[5] 고치원, "장애물 없는 생활환경 인증제도 시행", 도시정보, 통권 제 317호, pp. 22-26, 2008.

[6] 조민정 · 최상헌, "노인요양시설의 유니버설디자인 적용현황 및 개선방안에 관한 연구”, 한국의료복지 시설학회지, 제 15 권, 제 3 호, pp. 21-30, 8월, 2009.

[7] 이호성 최찬환 이특구, "무장애 주택설계에 관 한 국내외 국가표준의 비교 연구”, 한국의료복지 시설학회지, 제16권, 제1호, pp. 65-74, 2월, 2010.

[8] 국토해양부, “장애물 없는 생활환경(Barrier Free) 인증제도 시행지침, 2008.

[9] 국토해양부, "장애물 없는 생활환경 (Barrier Free) 인증심사기준, 2008.

[10] 김태호 · 도화용 - 원제무," "M-IPA분석을 이용한 버스서비스 지표 개발 연구”, 서울도시연구, 제 1 호, 제9권, pp. 1724-1738, 2008.

[11] 김태호 · 손상호 · 박제진, "M-IPA를 이용한 장애 인과 일반인 지하철 이동시설 만족도 비교 연구”, 한국토목학회논문집, 제29호, 제6권, pp. 703-709, 2009.

[12] 김태호 하종문 임종문 · 박제진, "중요도-만족 도 분석을 활용한 서울시 수상택시 이용자 서비스 지표 분석", 대한토목학회논문집, 제 29호, 205권, pp. 587-595, 9월, 2009.

[13] 박창선, "공공업무시설의 장애인편의시설 실태조 사에 관한 연구”, 한국의료복지시설학회지, 제 11 권, 제3호, pp. 41-49, 11월, 2005.

[14] Martilla,J. and James, "Importance-Performance Analysis, Journal of Marketing, 1997.

[15] Nunally,J.C Phychometric Theory. New York : McGraw-Hill.1978. 
최 서 연(Seo-Yeon Choi)

[정회원]

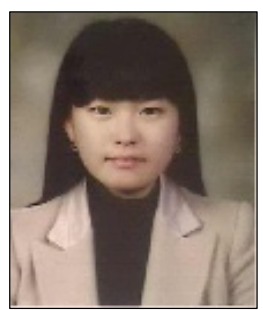

- 2009년 2월 : 경성대학교 도시공 학과 (공학사)

- 2009년 3월 현재 : 경성대학 교 일반대학원 도시공학과 석사 과정 재학

<관심분야>

도시계획 및 경관설계, 베리어프리, 유니버설디자인

이 석 환(Seok-Hwan Lee)

[정회원]

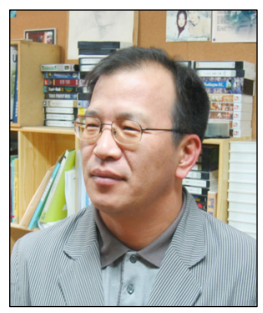

- 1987년 2월 : 서울대학교 공과대 학 건축학과 졸업 (공학사)

- 1991년 2월 : 서울대학교 환경대 학원 (환경조경학석사)

- 1998년 2월 : 서울대학교 환경대 학원 (공학박사)

- 1999년 3월 현재 : 경성대학 교 도시공학과 정교수

<관심분야>

도시계획 및 설계, 도시경관, 장소성, 도시재생과 문화

신 강 원(Kang -Won Shin)

[정회원]

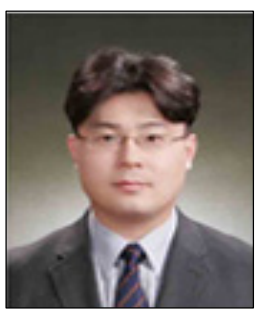

- 2001년 2월 : 아주대학교 교통공 학과 졸업 (공학사)

- 2003년 2월 : 아주대학교 건설교 통공학과 교통계획/ITS (공학석 사)

- 2008년 2월 : Arizona State University, 교통안전/ITS (공학 박사)

- 2209년 3월 현재 : 경성대학교 도시공학과 전임강사

<관심분야>

도시교통정책, 교통안전, 교통계획, 교통계량분석 